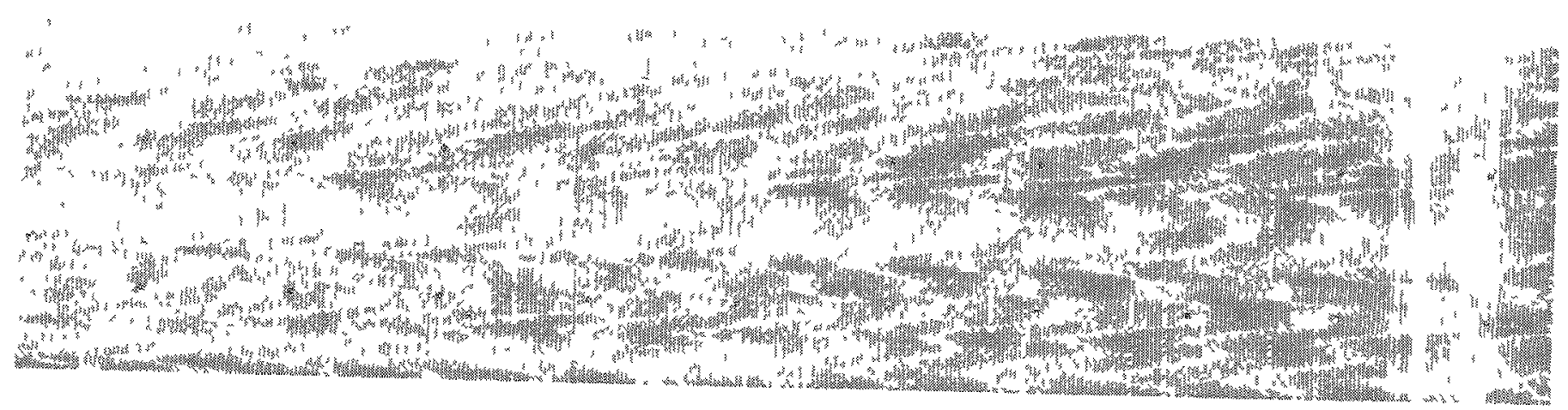

\title{
An historical-anthropological approach to Islam in Ethiopia: issues of identity and politics*
}

\author{
JON ABBINK \\ (Afrika-Studiecentrum, Leiden)
}

\begin{abstract}
Islam and Islamic populations in Ethiopia havebeen relatively understudied since the great survey of J.S. Trimingham published in 1952. Ethiopian Islam is interesting both because of its antiquity (since the inception of Islam itself) and because of the particular patterns of interaction and symbiosis with an, until recently, predominantly Christian culture. A sociocultural and historical explanation of patterns of tolerance of Islam and Christianity since the 16th century deserves to be developed. In addition, the relationships between religious and ethnic identification among Ethiopia's diverse populations are not well known and need further scrutiny.

In the last decade, new issues of religious identity and communal political identity of Muslims in Ethiopia emerge in the wake of the political and socioeconomic reforms in federal Ethiopia and the impact of 'globalization' processes in the cultural sense. While Ethiopians Muslims have in recent years gone through a phase of revivalism and self-assertion, they have remained rather impervious to 'fundamentalist' ideological movements in both a social and political sense.

This article gives a brief historical overview of Islam in Ethiopia, its position in the pre-1974 empire and its relationship with Christianity, and the changes under the Communist Mengistu regime up to 1991. Finally some of the major changes since 1991 are discussed, presenting challenges for debate and further socio-historical research on the place and role of Muslims in Ethiopia and on the

relationship of Islam (and Christianity) with 'modernity', ethnicity and group
identity in Ethiopia.
\end{abstract}

* An earlier version of this paper was presented at the seminar 'Islam as a Globalizing Project,' Globalization Research Group, African Studies Centre (Leiden), 29th April 1998. I am indebted to members of the research group and others present for their
comments and criticism. 


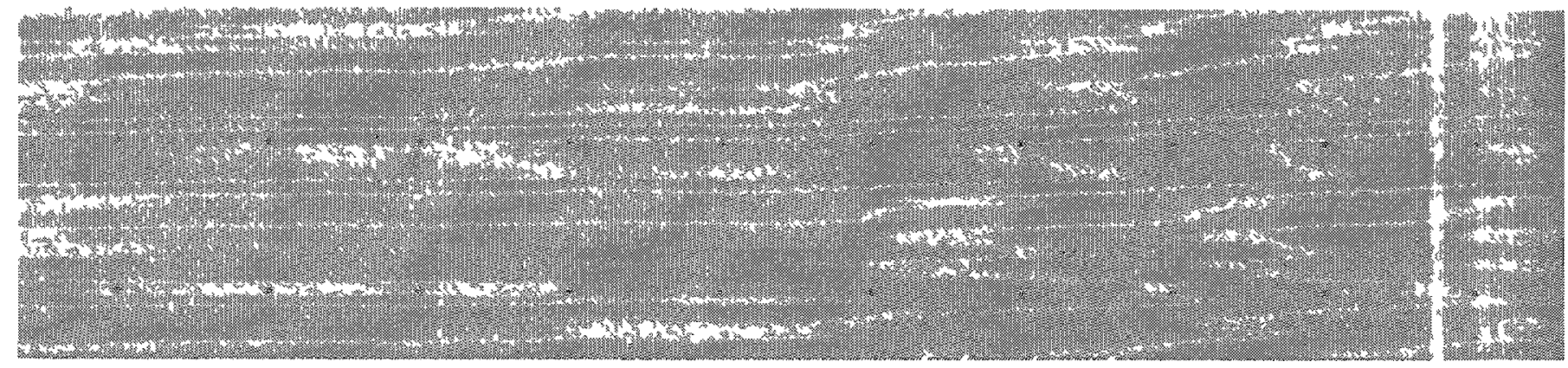

happened in several other African countries (notably Malawi, Sudan and Nigeria), where earlier patterns of co-existence between Christians and Muslims are being redefined in the context of emerging 'fundamentalisms.' This question is in fact one relating to the social foundations of Islam in Ethiopia and to the political culture of an ex-imperial state.

\section{Background}

From its very inception, Islam has been a trans-continental religion, in this case helped by the proximity of the African Red Sea Coast to the Arabian heartland where it first emerged. In fact the first converts to the new religion - outside the close circle of the Prophet Muhammad - are assumed to have been Ethiopians. In the year 615, so tradition goes, the first Hijra occurred: a group of Arab followers of Islam in danger of persecution by the dominant Quraysh authorities in Arabia (Mecca) were advised by Muhammad himself to seek refuge across the sea, in the empire of Aksum, where a '... righteous king would give them protection.'

These refugees were indeed well-received in Aksum and could practise their faith freely. Requests from the Meccan authorities to deliver them back were refused. The tolerant attitude of the Ethiopians gave rise to a whole new genre of Arab literature extolling the virtues of 'the Ethiopians.' The practical effect was that on the authority of the Prophet himself Ethiopia was not to be seen as a target for jihad. Undoubtedly there is an economic side to the story: Aksum was in decline, and the trade from and to the empire was not as attractive as that in the Middle East, to which the attention of the Islamic conquerors was directed. In the decades following the death of Muhammad, however, there were various armed clashes between Ethiopians and Arabians and raids by both sides (see Cuoq 1981: 36-38), also related to the control of the Red Sea trade.

The new faith did not, however, attract many followers in Ethiopia, certainly not in the highland Christian areas. ${ }^{2}$ Its expansion was very gradual and mainly took place in the lowland coastal areas inhabited by pastoral nomads, spreading later (eleventh-twelfth century) to the Somali areas in the south-east.

While Ethiopia was thus one of the first countries to receive Islam (later developing centres of Islamic learning in Harar, Massawa, Zeyla, later Jimma), it has also seen a notable tendency towards inward orientation, displaying the kind

1 Tradition cited in Trimingham (1952: 44). However, the first (Arabian) converts from Islam to Ethiopian Orthodox Christianity can also be traced back to this episode: some of the exiled stayed on in Aksum and became Christians.

2 Although Arab-Islamic legends predictably claim that the king of Aksum at the time (called by Arab sources Ella Asham) converted in secret to the new faith, after a letter from the Prophet Mohammed. For more on the Islamic mythology, see Hussein (1996). For an excellent overview of this period and a critical review of the sources, see Cuoq (1981: 128-38).

During a December 1997 symposium on the Ahmed Nejash mosque in Meqelle (Tigray), attended by the ambassadors of Iran, Turkey, Yemen and Libya, and officially opened by the presıdent of Tigray Regional State, the (highly controversial) assumption was that "Ahmed Nejash" was the "first Ethiopian Muslim king" (Addis Zemen, Ethiopian state newspaper, 9 December 1997). 


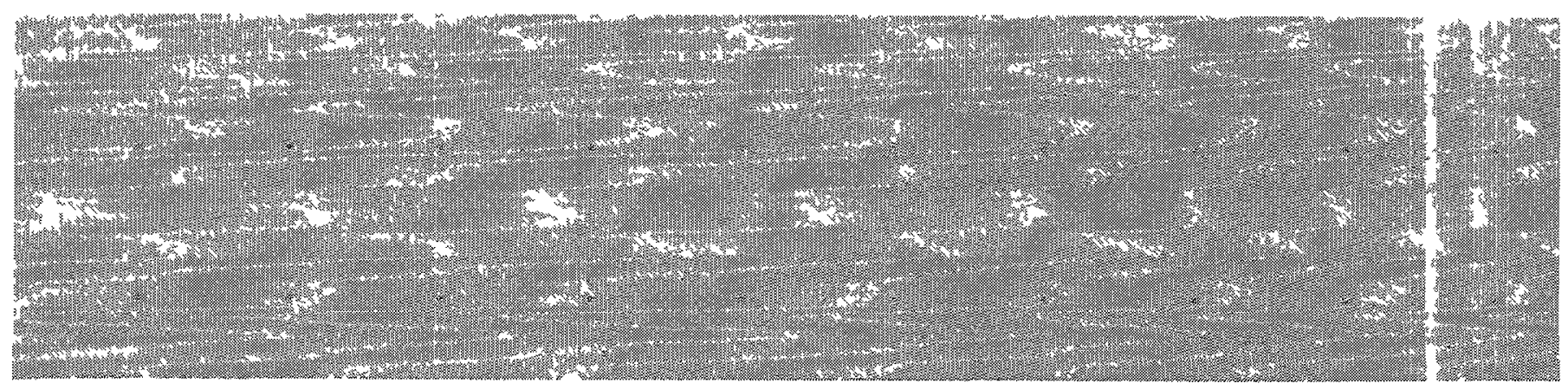

\section{Jon Abbink}

of seclusion and self-sufficiency that was equally characteristic of Ethiopian Christianity. In addition to the geographical reasons for this, linguistic and cultural factors probably also played a part. Arabic never was and never became an indigenous spoken language ${ }^{3}$ - even most Ethiopian Muslims only knew Quranic passages and prayers in Arabic (cf. Drewes 1976) - and for many purposes ethnic and regional identities tended to be as important as religious identity (see below).

\section{Distribution}

At present, at least $30 \%$ of the Ethiopian population professes Islam. ${ }^{4}$ The religion cannot be identified clearly with particular regional or ethnic groups ${ }^{5}$ and is found across most of them. Islam is strongly represented in the north-east, east and south-east and a small strip in the west of the country (Afar, Harari, Argobba, Somali, Garri, part of the Oromo, part of the Gurage, Beni Shangul).

In Ethiopia - where since the fourth century a deep-rooted Orthodox Christian religion was predominant, especially in the highland plateau - Islam largely spread by peaceful expansion, via trade routes and itinerant teachers (many of Yemeni and Arab origin), tolerated by the Christian monarchs. This tolerance can be explained by a variety of reasons, among them the particular hierarchical social structure and ethos of the Amhara-Tigray Christians - amongst whom craft-work and regional and international trade were somewhat despised activities, in favour of soldiery, peasant-farming, administration and priesthood and by the emerging international slave, gold and ivory trade from Ethiopia, fuelled by Arabian, Yemeni, Hadramauti and Swahili entrepreneur-traders especially from the twelfth century. The presence of Islamic groups and

3 Only the Rashaida people in Eritrea, a group ('tribe') of about 5-6000 people that emigrated from Arabia to Ethiopia in the early nineteenth century, had Arabic as its mother tongue. For a valuable study on the status and use of Arabic (mainly as a written language) in Ethiopia, see Drewes (1976). This author, a leading authority on the Semitic languages of Ethiopia, mentions the fact that Amharic has long been an important language of Islam in Ethiopia, both in ceremonies and in written texts, although few of the latter have appeared in print (1976: 184).

4 On the basis of the faulty idea that numbers equal importance, a highly partisan presentation of statistical material on the number of adherents of the various faiths in Ethiopia (as on that of the ethnic groups), is repeated time and again by various authors, without mention of any serious source. E.g. Seifuddin, in a rather flawed paper (1997: 136), writes of Muslims as being the majority group in Ethiopia, but again his source is unclear.

The best course, however, would be to take the Ethiopian censuses of 1984 and 1994 as indicative (they too have a measure of error, but it is a slight one, and evenly spread). The 1994 census (the official document cited in Ethiopian Register 6(1), 1998 , p. 52) gives the number of Muslims in Ethiopia as 14.3 million, or $28.7 \%$ of the population. The 1984 census had counted Muslims as 12.5 million, or $32.9 \%$ of the population). It has to be noted that the 1994 census left out Eritrea: independent since 1993 (ca. 50\% of its people - some 1.8 million - are Muslims). In both censuses the Orthodox Christians are the numerical majority, with more than $52 \%$.

5 Except the numerically less significant Somali, Argobba, Beni Shangul/Berta and Afar, who are virtually all Muslims. 


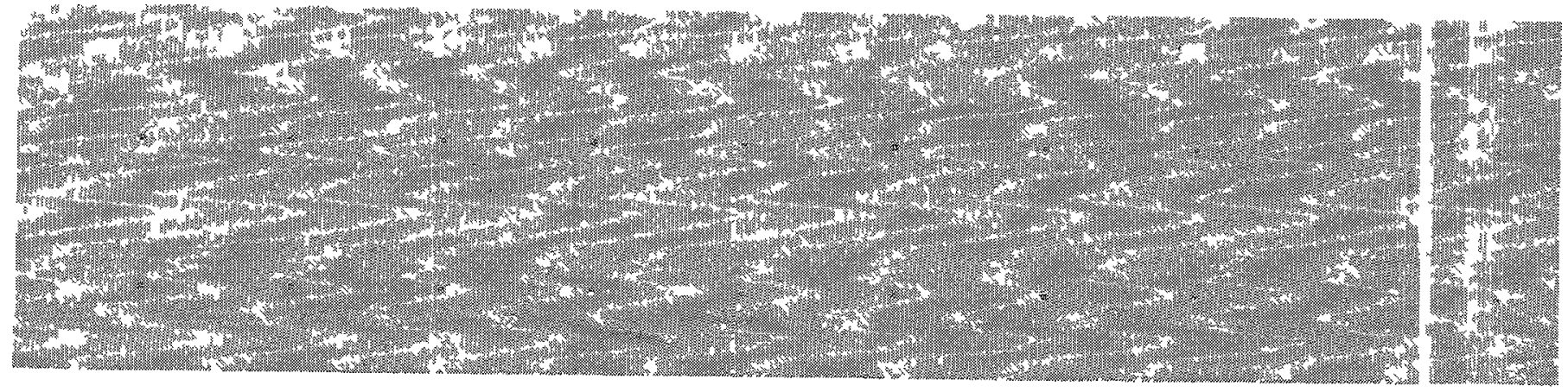

sultanates deep in the heartland (e.g. Dawaro, Hadiya, later Jimma) at a relatively early date (late thirteenth-fourteenth century) may partly be explained by a strategy of self-protection: in these areas outside the purview of the Solomonic monarchy, conversion to Islam exempted the people from being enslaved.

Arab traders, teachers and entrepreneurs have settled in the country and intermarried with Ethiopians, but on a rather limited scale. Ethiopian Muslims do not derive from 'Arab stock' but are indigenous, belonging to the various ethnic communities of the country. They only rarely trace descent from prestigious Arab lineages (an example is the Mirghani family in Eritrea, see Hiskett 1994: 143). Some holy men or sheikhs who did so have become the object of veneration and pilgrimage.

\section{Historical patterns}

The emergence and identity of Ethiopian Islam has been inextricably linked with the nature of the Ethiopian state and its economic base, and with Ethiopian Orthodox Christianity (and vice versa). Both religions are part of one ideologicalreligious framework rooted in a multi-ethnic Ethiopian culture. Thus, the one cannot be understood without the other. They have had their phases of violent antagonism and confrontation but in the past centuries have evolved a modus vivendi of practical everyday co-existence and co-operation, especially in the last three centuries. This modus vivendi was grounded in the economic activities of the Muslims, who introduced trade in and markets for new products, serving as pioneers intensifying trans-national commercial trade relations with countries outside Ethiopia, and also in common elements in the underlying cultural fabric of Ethiopian societies. ${ }^{6}$

Nevertheless, one fact stands undisputed: despite its ancient history and roots in the country, Islam in Ethiopia has always been a religion with secondary and, in the eyes of many Ethiopian leaders inferior, status; it emerged in the shadow of Christianity and often suffered from suppression and discrimination. This has had its impact on social opportunities, religious and civil rights and the patterns of self-organization of the Muslims.

Due to its link with the 'divinely ordained' Solomonic monarchy, Christianity inevitably was the core world-view of the political elite and a defining element of nationhood in a historical sense. Moreover, a majority of the population has adhered to Christianity since later Aksumite times.

\subsection{The seventh century}

Since its arrival in the seventh century, Islam only expanded in a modest way, without spectacular growth. The arid and sparsely populated Dahlak Islands off the Eritrean coast were the first fully Islamic region where a sultanate emerged. On the mainland, Islamic sultanates were founded from the twelfth century, and their rulers paid tribute to the Ethiopian kings, who since ancient times had

6 It is, for instance, notable that a social trat like patrilateral cross-cousin marriage (widespread in Arab countries) is strll very rare among Ethiopian Muslims, perhaps only to be found among the Afar and the Somali. 


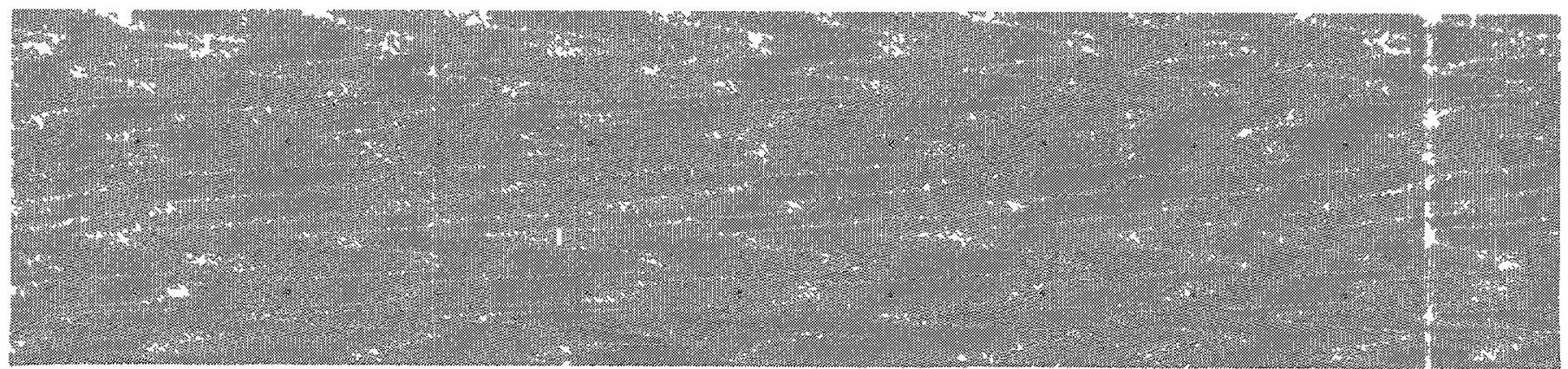

\section{Jon Abbink}

claimed sovereignty over the lands up to the coast. Whenever the sultanates refused to pay, violent conflicts ensued. These conflicts marked the foutteenth and fifteenth centuries, with the Christian empire usually emerging the winner (although important direct-trade revenues were lost to the sultanates, e.g. Yifat and Adal, see Hiskett 1994: 140). ${ }^{7}$

\subsection{The sixteenth century jihad}

In the first half of the sixteenth century, under the leadership of a skilled soldier and Islamic revivalist Ahmed ibn Ibrahim al-Ghazi (nicknamed Gragn, the 'lefthanded'), the new sultanate of Adal (with its centre in the city of Harar) became so strong that a full-scale jihad was launched against a weakened Ethiopian state. His forces received essential help from Arab mercenaries and from the Turks, who had been encroaching on the coast up to the city of Massawa, and who supplied fire-arms, cannons and matchlock men from their own army to the Adal forces (the Christian armies did not yet have fire-arms). The stated aim of this war was to root out and destroy Christianity in the area and to end the Solomonic monarchy (which had been reinstated in 1270). ${ }^{8}$ The havoc and destruction wrought by this 14-year war (1529-1543), during which virtually the whole of Highland Ethiopia was conquered and a great number of centres of Ethiopian Christian civilization were destroyed, long shaped the Christian perception of Muslims as the 'danger from within.' The jihad was finally ended by Christian 'guerrilla' resistance and with the help of a contingent of Portuguese soldiers sent upon the request (in 1535) of the Ethiopian king and whicharrived in 1541. Ahmed ibn Ibrahim was killed in 1543. His successor Nur ibn al-Mujahid, who continued the war until his death in 1568, was less successful. Although Emperor Gälawdewos was killed in 1559 , the Christian empire recovered under emperors Minas (1559-1563) and especially Särșä Dingil (1563-1597).

The background to the conflict was again the struggle for control of internal and especially external trade routes. The Turkish-Portuguese rivalry can also be explained in this light. Nevertheless, the deeply ideological-religious aspect of this war should not be neglected.

\subsection{The Gondarine monarchy (sixteenth-seventeenth century)}

The imperial state revived in the late sixteenth century and flowered until the 1730s. A new imperial capital emerged in the town of Gondar, stimulated by Emperor Fasilädäs (r. 1632-1667). The policy of the Ethiopian emperors was one of tolerance vis-à-vis Muslim traders and middlemen, but also reservations against employing them in important positions in the Christian-dominated state service and in the army. As a rule, Muslims were also excluded from obtaining the hereditary land right ( $r i s t$ ), which was a defining element of highland Ethiopian Christian culture (among people of Amhara and Tigray). Internally, the Muslim communities were accorded autonomy, e.g. in matters of religious law.

7 It is interesting that in some of the contemporary chronicles the Muslims were described as the 'infidels'; see Cuoq (1981: 136).

8 The contemporary source is Chihab ed-Din (Arabfaqih) (1897). 


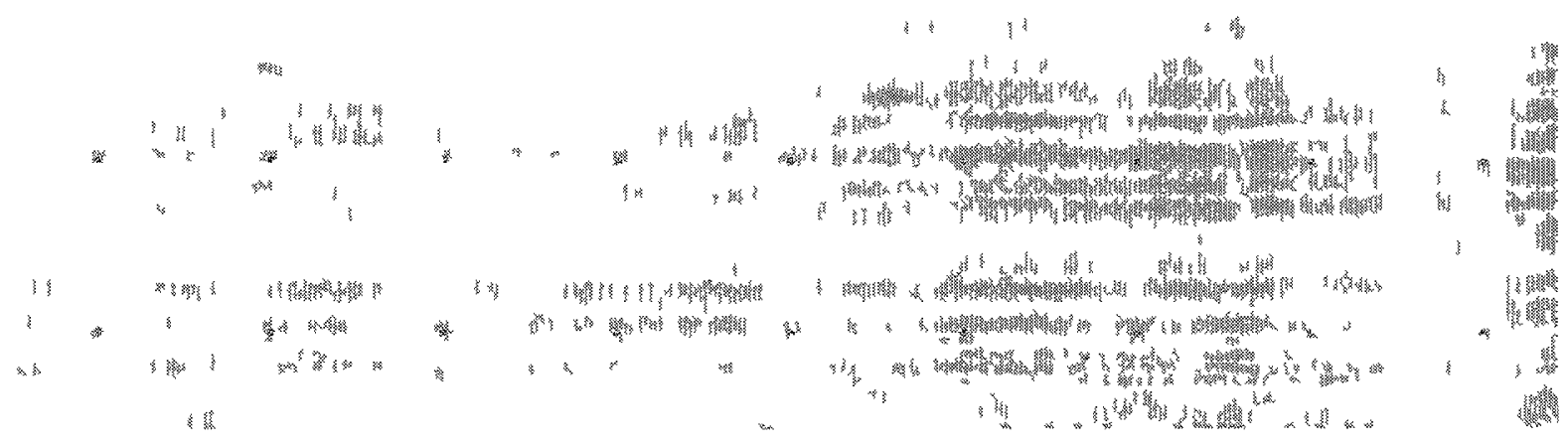

Islam in Ethiopia: issues of identity and politics

though not exclusively, at the expense of the indigenous population, were in many areas dismissed, expropriated and forced out by the Italian government. The exploitative peasant labour corvée (gabbar) system which still existed in many areas was ended by the Italians, and this was seen as a liberation by many of the rural underclass. The Italians systematically favoured the Muslims in Ethiopia at the expense of the Christians. They provided full freedom of religion for Muslims, stimulated Islamic education and the introduction of Arabic in schools, built fifty new mosques, and supported Muslim leaders financially (Hussein 1994: 776). The Muslims thus largely welcomed Italian policy, and this did not endear them to the Ethiopians fighting for national liberation.

The problems of integration and of the shaky Ideological basis of the unitary state were also revealed in the course of the guerrilla war of the Patriots (the Ethiopian resistance fighters in the provinces) against Italian occupation. They were mostly Ethiopian Christian highlanders, and after several battles with the Italians, the retreatıng Ethropian Patriot forces were attacked and killed by Muslim Oromo (e.g. in Wollo, cf. McClellan 1995: 70-71), who saw the ItaloEthiopian war as none of their business (though they were armed and encouraged by the Italians) and considered the highland Christrans as much their enemies as the Italians. Such incidents in their turn increased the animosity of highland Christians towards the 'treacherous Muslims' in the lowlands.

\subsection{The post-Haile Sellassie era}

After the era of Emperor Haile Sellassie, characterized by a policy of repressive tolerance and only a partial granting of rights to Muslims, the socialist-oriented military regime (known as Derg) came to power. Under this Derg regime (19741991) there was active discouragement of religion in all its forms, and both Christianity and Islam were the target of state propaganda and subversion. In the view of the regime, religion being 'false ideology,' 'backward,' and 'ant1development,' was systematically weakened The first measures taken aimed to reverse the privileged position of Christianity: for example, the Church lost all its land, its immovable property was confiscated, and religious education in schools was proscribed. Policies were devised which aimed at changing the religious culture of the population. However, the large number of Christians and Muslims as well as the deep-rooted religiosity of most Ethioprans was a social factor which could not be ignored by the regime, so it settled for a policy of coexistence and co-optation. It rhetorically granted religion, especially Islam, a new public status and equal rights, recognized the most important Christian and Islamic religious festivals as public holidays, and tried to give ceremonial recognition to the two communties, e.g. by making their leaders appear at state occasions. But the practical exercise of religion and the social basis of religion among the population at large was discouraged and sidetracked in many ways. ${ }^{10}$

10 In the various rebel movements that waged armed struggle against the Derg, Islam played a role as a mobilizing ideology, but these movements (apart from the Afar movement ALF) never attaned solid mass support This was the case for example with the SALF ('Somali Abo Liberation Front') and the WSLF ('Western Somalı 


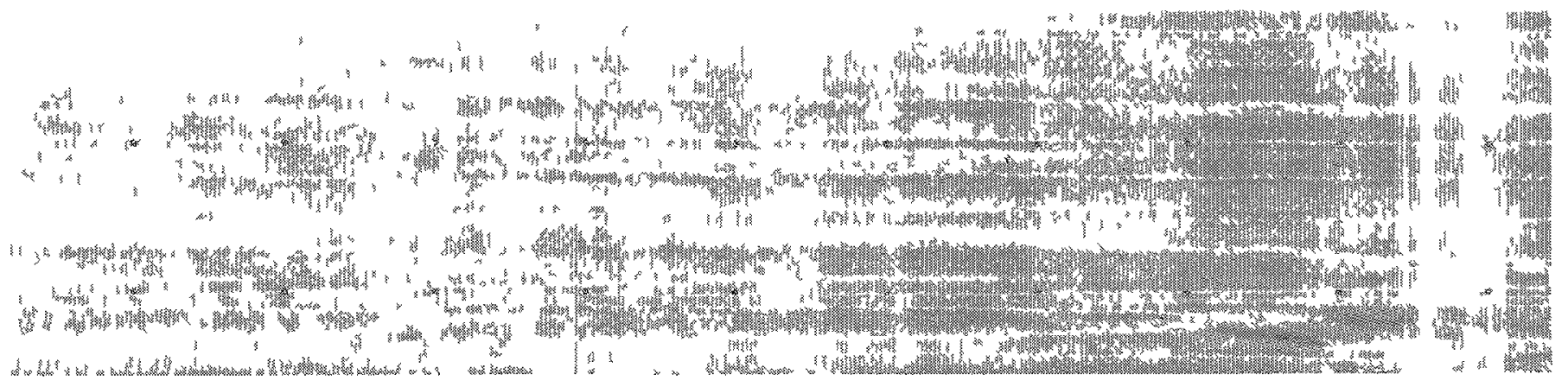

Islam in Ethiopia: issues of identity and politics

Social factors determining this are marriage, trade relations, migration to a city or an area predominantly inhabited by members adhering to the other religion, and even (today especially) ethnic or political affiliation.

This cultural phenomenon of what I term religious oscillation has not been studied systematically ${ }^{13}$ but is of great interest: it shows not only the varied forms that Islamic religious culture can take in an African context (it is found also e.g. in parts of Nigeria, Cameroon and Mali), but also leads us to inquire into the nature of (Islamic and Christian) religiosity and into conditions of coexistence and non-exclusivist identification on the basis of religions usually held to be exclusivist and - in the case of Islam - not tolerant of conversion to another faith.

Long-standing cultural affinities between Ethiopian Christians and Muslims (and others), questions of land inheritance, and social and kinship organization may have provided the main reason for this pattern of oscillation and for the religious tolerance associated with it. Another has undoubtedly been the limited impact of urban-based 'scriptural religion' as defined and prescribed by the ulema class, often coming from Arab-Islamic centres of learning: both this class and important urban centres were absent in pre-twentieth century Ethiopia, with the exception of Harar.

\section{7. 'Ethnic dimensions' of Islam}

A factor which has enhanced the everyday pattern of tolerance and pragmatic coexistence between adherents of the diverse religions may have been that of the ethnic diversity and the rich indigenous culture of Ethiopia. An understanding of Islam in Ethiopia must be grounded not only in the apprehension of the context of Ethiopian state formation and political authority but also in a study of the interaction of indigenous culture with the tenets and idiom of the Islamic faith. ${ }^{14}$

In anthropological studies on the various ethnic groups of Ethiopia many varieties and forms of Islamic practice have been described. What is clear is that Islam and ethnicity are not isomorphic: moreover, among the overwhelmingly Christian Amhara people, there is a sizeable number of Muslims (in the Gojjam, Wollo and Gondar regions).

To look at the 'ethnic roots' is also important because several similar cultural institutions and customs are found across defined ethnic groups, be they of Christian, Muslım or traditional religion. Characteristic are:

- a blend of 'traditional,' so-called pre- or non-Islamic rituals, practices and beliefs with 'official' Islam. Among these can be counted magical practices, initiation, spirit possession and certain (not all) divination methods. This Ethiopian (African) heteropraxis has a tenuous legitimacy in the eyes of orthodox literate Muslims, especially non-Ethiopians.

13 But it will be part of future research in the Wollo area.

14 A fascinating example of this interaction is described in A. Pankhurst's article (1994a). 


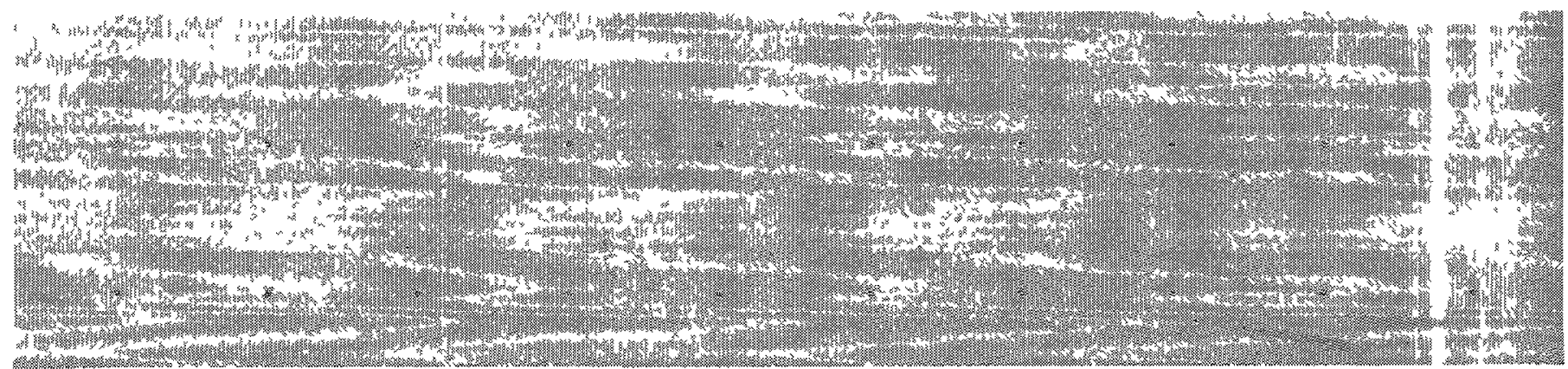

\section{Jon Abbink}

- the importance of (past) saints and holy men (awliya) and the pilgrimage to their tombs. This is widespread in Ethiopia (prime examples are the locations of Sheikh Hussein in Balé, and Faraqasa in the Arssi region). Interestingly, in Ethiopia Christian pilgrimage places also draw Muslims, and vice versa (for one example see Abebe 1995: 31-32). Ethnic and religious boundaries often blurr in the worship of many such pilgrimage sites (see Pankhurst 1994b).

- the important role of the Sufi mystics and orders (pl. turuq). These have also been important in the spread of Islam, e.g. the Qadiriyya (since the sixteenth century), and the Sammaniya and Tijaniyya (nineteenth century). Conversion in many areas meant becoming member of a Sufi order. Among groups where traditional initiation and ritual fell into disuse (perhaps in the western Oromo areas), the entrance into a tariqa (Sufi order) was the logical alternative. The role of the turuq in Ethiopia, is however, another subject on which remarkably little is known (see Trimingham 1952, and Abebe 1995 for some recent information).

Islam in Ethiopia has been moulded by these and other elements from the cultural and ethnic traditions of the country. The Ethiopian societal context has, so to speak, forced the idea of 'pluralism' not only on the minds of the country's Christians but also on that of its Muslims.

These phenomena also raise the question of the relation between 'folk Islam' and 'scriptural Islam,' 'saint' and 'doctor'' to refer to the well-known though controversial point made by E. Gellner on Muslim society (Gellner 1981: 114f.). In its original formulation, this dichotomy may have been too 'essentialist,' but it does point to an undeniable status hierarchy in Islam. In an interesting analysis of the Argobba Muslims in Ethiopia, Abebe (1995: 29) has claimed that both poles in Gellner's model are not only complementary (and can be mediated by Sufi orders), but can also be interpreted within the framework of Islamic orthodoxy.

Without pursuing this discussion here, I want to make the point that in the areas of this above-mentioned symbiotic and oscillating religious identification, one sees a form of non-literate folk Islam which does go against the grain of strict Islamic ulema doctrine: if strictly applied, Islam, in this view, 'should not allow' this kind of flexible behaviour.

Indeed, in recent years, after the 1991 change of regime, these very patterns of tolerance (in Wollo and elsewhere) have been the target of a movement of itinerant teachers/preachers of 'true Islam.' In 1994 during interviews in the Aliyu Amba area (a traditional mixed border-area in east-central Ethiopia where Islamic and Christian people live together in the villages), it was remarkd to me by some people that their village had been visited by persons who came and asked them to reduce their contacts and co-operation with the Christians, and to reinforce the 'Muslim character' of their village and their way of life.

Schlee (1994: 988-999), in an important study of changing relationships between Boran, Gabbra, Garri and Somali in southern Ethiopia, has in a similar vein noted the problems of a new Islamic identity intersecting with ethnicity, disturbing the local co-existence of groups. 


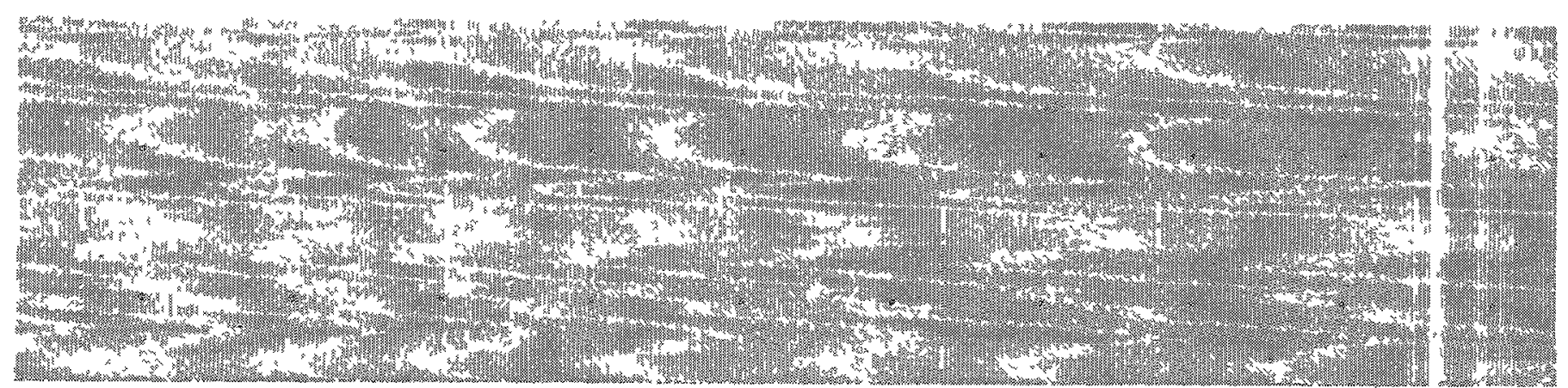

Islam in Ethiopia: issues of identity and politics

It is likely that such local-level developments - which can, however, only be understood in the changing configuration of a globalizing Islam that is expanding under new social and political conditions - will reshape the social fabric of Islamic societies in Ethiopia and the nature of Muslim identity and identification in the country. Villagers will be drawn into a wider debate, initiated by globally oriented scriptural Islamic community leaders or missionaries, on Islamic ideals and practice. The present climate in Ethiopia of politicizing everything, from personal identity and choice of friends to economic activity and elementary development work, will enhance this development.

\section{Prospects}

In an economic sense, the Ethiopian regime is at present making an accelerated effort to insert itself in the global economy: it liberalizes markets, invites foreign private investment, co-operates with the IMF and World Bank in a Structural Adjustment Facility, privatizes state companies, and devolves central state power to regions, all the time, however, maintaining the 'ethnic balance' in its own favour. People from the northern Tigray region and loyalists from other groups control the key positions in national politics and business, and religious organizations of Christians and Muslims are largely co-opted. ${ }^{15}$ The political discourse in present-day Ethiopia, after the demise of the Ethio-Communist Mengistu-regime with its meta-narrative of state-socialism, areligiosity and the unitary state, has dissolved all conflicts and social issues of nation-wide importance into ethnicity. Ethnic identity is - rightly or wrongly - seen and defined by the Ethiopian regime as the determinant of political debate, of economic and educational policy, and of regional and local administration. It is held to be the 'vessel' or prism through which people's democratic rights are realized. Religious identification has also been drawn into this: one is not Muslim or Christian but one is Oromo or Afar Muslim and Amhara or Gurage Christian. There is, however, a struggle for allegiance going on between religion and ethnicity.

Except in a formal manner, the question of national integration or cohesion is hardly posed in Ethiopia: each ethnic (and religious) community has been accorded the right and duty to manage its own affairs in the shadow of a federal government providing the semblance of unity. The models and ideals of searching for common ground and patterns of trans-regional, trans-ethnic and trans-religious co-operation are de-emphasized, in view of the past problems posed by diversity, suppression and social inequality. This is perhaps an interesting societal model: it carries a radical recognition of diversity and of a

15 It is ironic that at present the largest private investor in Ethiopia today is a Muslim business tycoon, Mohammed al-Amudi (from an Ethiopian-Saudi family), the wealthiest man in the region, with an extending global network of interests. He does not style himself as a Muslim revivalist but primarily as an Ethiopian of Muslim faith committed to national development and business. He has funded Muslim educational programmes and the building of many mosques in Ethiopia, but his charitable trust also supports Christian and non-denominational social or educational projects. 


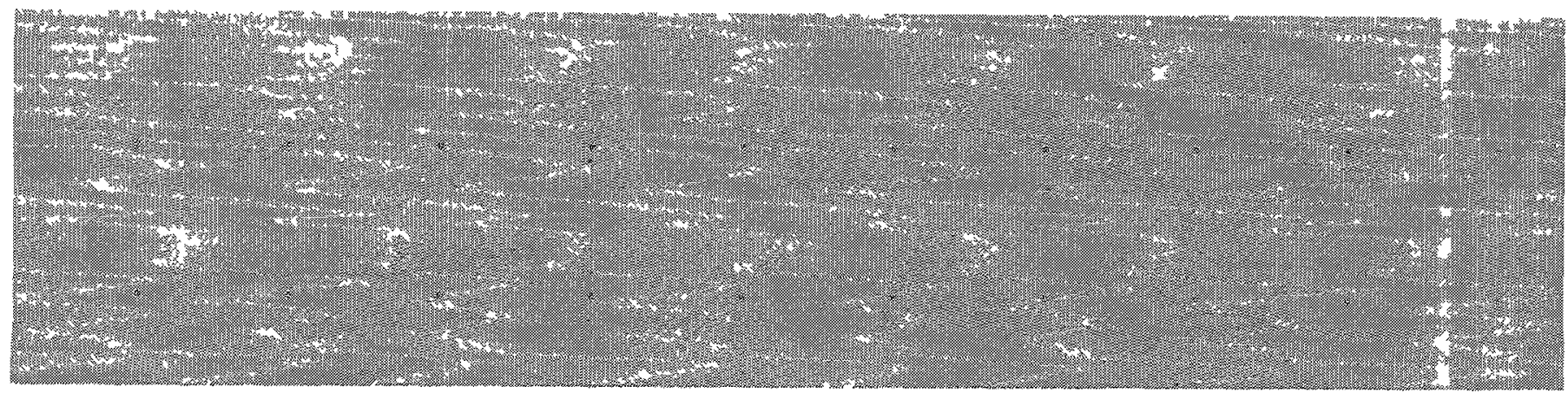

In this respect, 'fundamentalism' in its Islamic form exists on a state levellin Africa only in Sudan (with its National Islamic Front government), while other movements are active in Algeria, Egypt, Uganda, Tanzania, Kenya, Somalia, Senegal and a few other countries. In Ethiopia such a movement is absent,"and will not find fertile ground for any mass allegiance. ${ }^{18} \mathrm{My}$ hypothesis is thus that social and cultural conditions for the emergence of political Islam in a 'fundamentalist' or, better, Islamist form are not good in Ethiopia. Ethnicity, socio-economic factors and the specific nature of the Ethiopian state (especially in its present federalized form) ${ }^{19}$ will transect any homogenizing tendencies of an 'Islamic identity' on a collective basis. However, Islamic revivalism and the striving for and maintaining of full equal rights for Muslims as citizens in a postideological, ${ }^{20}$ 'ethnicized' Ethiopia will continue (paralleling renewal developments in the Orthodox Christian Church, and especially in Pentecostal movements in Ethiopia). Whether this quest will ultimately take a political form is doubtful. The Ethiopian government has become embroiled in verbal warfare with the Islamist regime in Sudan and in actual armed struggle in Somalia against some Islamist Somali groups like Al-Ittihad, operating in the southern border area. The government also keeps a close watch on similar-minded groups in Ethiopia like the IFLO (= Islamic Front for the Liberation of Oromia), a minority Muslim movement among the Oromo with an exclusivist and anti-Christian programme. The initial openness of the present government toward the Muslim world and toward Islamic revival in Ethiopia may thus be gradually reversed. Furthermore, if in the longer term the ethnicity-oriented state policy fails, Islam may become a major vehicle for mobilizing political, economic and ethnoregional groups in Ethiopia. The context of Islam as a global narrative will prove to be essential here in further defining the self-image and socio-political role of the Muslims in Ethiopia.

In view of the above, the process of Islamic revival in Ethiopia - as evident in the new written media, self-organization and proselytizing - together with the forms of expression of Islamic identities among the various major ethnic groups of the country will provide a fruitful as well as urgent area of study.

JON ABBINK may be contacted at the Afrika-Studiecentrum, P.O. Box 9555, 2300 RB Leiden, the Netherlands (e-mail: abbink@rulfsw.fsw.LeidenUniv.nl, fax: (+) 31-71-5723344).

18 In Eritrea small groups exist. They have partly emerged from the defeated ELF (Eritrean Liberation Front, a Muslim-dominated movement) in the early 1980s (see Tesfatsion 1994: 78-80). At present there is an Eritrean Islamic Jihad Movement active, formed in 1988, with bases in Sudan and supported by the NIF-regime (despite the latter's habitual denials).

19 In which Islamic parties are - as in Eritrea - forbidden. Neither has there been a clamour among the public for 'Islamic' (or 'Christian') political parties, as for example in Kenya.

20 I.e. non-Christran (up to 1974) and non-Communist/Socialist (up to 1991) Ethiopia. 
